\title{
Histomorphometric Changes in the Testes and Epididymis of Wistar Strain Albino Rats Following Fourteen Days Oral Administration of Therapeutic Doses of Some Antibiotics
}

\author{
Cambios Histomorfométricos en los Testículos y el Epidídimo de Ratas Cepa Wistar Albinas \\ Después de Catorce Días de Administración Oral de Dosis Terapéuticas de Algunos Antiobióticos
}

"Awobajo, F. O.; "* Raji, Y. \& ***Akinloye, A. K.

AWOBAJO, F. O.; RAJI Y. \& AKINLOYE, A. K. Histomorphometric changes in the testes and epididymis of wistar strain albino rats following fourteen days oral administration of therapeutic doses of some antibiotics. Int. J. Morphol., 28(4):1281-1287, 2010.

SUMMARY: Studies on testes and epididymis tissue of rats treated orally for fourteen days with therapeutic doses of cloxacillin (6mg/100g/day), ampicillin (4mg/100/day) and tetracycline $(12 \mathrm{mg} / 100 \mathrm{~g} /$ day $)$ separately showed a significant reduction in testicular and epididimis architecture. Microscopic studies of these male reproductive organs further revealed a significant alteration in the epididymis as revealed by a significant reduction $(\mathrm{p}<0.05)$ in epididymal ductular diameter $(\mathrm{EDD})$, and epididymal epithelial height $(\mathrm{EEH})$ in treated group of animals. A significant increase $(\mathrm{p}<0.05)$ was however recorded in epididymal luminal diameter $($ ELD) in all the animals after the two and three week's recovery period allowed. This gives another insight into the toxicity activities of these antibiotics on male reproductive organs, apart from reduction in serum testosterone level, decreased sperm motility, decreased spermatozoa count and decrease in RNA and DNA content of spermatogenic cells as earlier reported.

KEY WORDS: Antibiotics; Testes; Epididymis; Histomorphometry.

\section{INTRODUCTION}

The reversible anti-fertility effects of many antibiotics on male reproduction have been well documented (Shlegel et al., 1991). These adverse effects have been shown on such parameters as serum hormonal level, reproductive organ weight, physical and chemical qualities of semen sample as well as spermatozoa quality, quantity and motility in the semen sample (Raji et al., 2006). There is however, scanty information on the testicular architectural assessment using histomorphometric analysis of antibiotics on testicular and epidydimal histology (Aumüller et al., 1985).

The use of histopathological evaluations, while evaluating animal tissue is of prominent role in male reproductive risk assessment. Organs that are often evaluated include the testes, epididymis, prostate, seminal vesicles, and pituitary. Histological evaluations are especially useful in providing a relatively sensitive indicator of damage; and with short-term dosing, providing information on target cells, extent of toxicity, and, indicating the potential for recovery. High quality information can be obtained on spermatogenesis from an adequately prepared testicular tissue (Russell et al., 1990; Hess \& Moore, 1993). The basic morphology of other male reproductive organs like the epididymis, and accessory sex glands have been described as well as the histopathologic alterations that may accompany certain disease states (Fawcett, 1986; Akinloye et al., 2002). Although, there is extensive documentation on effect of exposure to the toxic activities of antibiotics on spermatogenesis and spermatozoa morphology (Shlegel et al.), less is known about structural changes in the testis and epididymis themselves. With the epididymis and accessory sex glands, histologic evaluation is usually limited to the height and possibly the integrity of the secretory epithelium.

\footnotetext{
* Department of Physiology, College of Medicine, University of Lagos, Nigeria.

** Department of Physiology, College of Medicine, University of Ibadan, Nigeria.

*** Department of Veterinary Anatomy, University of Agriculture Abeokuta, Nigeria.
} 
In this research work, we use stereological analysis of the testicular and epididymal tissues to assess infertility in rats treated with the following antibiotics; Ampicillin, $(4 \mathrm{mg} / 100 \mathrm{~g}$ b.w./day) Cloxacillin $(6 \mathrm{mg} / 100 \mathrm{~g}$ b.w./day), Tetracycline (12mg/100g b.w./day), and their corresponding one and two weeks recovery groups.

\section{MATERIAL AND METHOD}

Animals and Treatment. Matured male Wistar albino rats (130-150grams) were used for this experimental study. There were ten (10) groups of eight animals each. They were provided with rat pellet and water ad libitum throughout the period of the experiment. The treated groups are as follows: Ampicillin treated group, AT, $(4 \mathrm{mg} / 100 \mathrm{~g}$ b. w./day); Cloxacillin treated group, CT, $(6 \mathrm{mg} / 100 \mathrm{~g} \mathrm{~b}$. w./day); and Tetracycline treated group, TT, (12mg/100g b. w./day). All the doses used were therapeutic doses calculated for the weight of the rats. The control group (C) received the same volume of the vehicle (distilled water) alone. The drugs were administered orally using separate sterilized oral dosing needle for a period of fourteen days. There were also two recovery groups of two and three weeks for each of the test or treated groups. The recovery groups were also treated with the antibiotics as their corresponding test groups after which they were allowed a recovery period ranging from two to three weeks respectively.

Body and Organ Weight. The initial body weight (IBW), weight during the experiment (WDE) and final body weight (FBW) of the animals were recorded for each group during the experimental period allowed. Rats were sacrificed by an overdose of pentobarbitone sodium $(45 \mathrm{mg} / \mathrm{kg}$ body weight ip, Sigma, USA) on the last day of the experiment. The animal abdomen was opened up and the prostate gland (PGW), testis (TW) and epididymis (EW) carefully dissected out. The fats are trimed of the organs and the wet weights measured using an electronic analytical balance (model WH200-4, by Hauser).

Histomorphometric Study. The tissues of the testes and epididymis were fixed in fresh Bouin's fluid and embedded in paraffin wax. Section of $5 \mu \mathrm{m}$ thick were cut and stained in haematoxylin and eosin. The testes histopathology was performed according to Sobarzo \& Bustos-Obregon (Cited by Bustos-Obregon \& Gonzalez-Hormazabal, 2003). The tissue sections were observed under a light microscope (x400 objective) for histomorphometric changes according to Akinloye at al. and Glander (1984). The seminiferous tubular diameter (STD), epididymal epithelial height (EEH), epididymal ductular diameter (EDD), epididymal luminal diameter (ELD) of 50 cross sections per animal were measured, using calibrated eye-piece micrometer (Graticules Ltd. Toubridge Kent).

Statistical Analysis. Results were expressed as Mean \pm SEM and analyzed using ANOVA. The test of significance was placed at $\mathrm{p}<0.05$. Bar charts were also used for graphical representation.

\section{RESULTS}

Body and Organ Weight. In all the treated groups and the counterpart recovery, the body weight was not significantly different from the control group (Table I). The relative weight (in percentage) of the testis were significantly decreased $(\mathrm{P}<0.05)$ in cloxacillin treated group and the cloxacillin recovery group only. The cloxacillin and tetracycline treated groups and their respective recovery groups exhibited a significant decrease $(\mathrm{P}<0.05)$ in the epididymal weights.

Table I. Male reproductive organ weights in rats treated with ampicillin, Cloxacillin and tetracycline and their corresponding weight after two weeks of recovery.

\begin{tabular}{|c|c|c|c|c|c|}
\hline Group & Control & AT & ATR 2wk & ATR 3wks & CT \\
\hline FBW (g) & $150.50 \pm 5.48$ & $170.00 \pm 0.00$ & $148.33 \pm 2.70$ & $140.00 \pm 0.00$ & $160.00 \pm 0.00$ \\
\hline TW (\%) & $0.58 \pm 0.04$ & $0.40 \pm 0.08^{*}$ & $0.38 \pm 0.07^{*}$ & $0.48 \pm 0.04$ & $0.41 \pm 0.03 *$ \\
\hline EW (\%) & $0.18 \pm 0.01$ & $0.09 \pm 0.03^{*}$ & $0.16 \pm 0.02 \dagger$ & $0.17 \pm 0.04 \dagger$ & $0.09 \pm 0.02 *$ \\
\hline Group & CTR 2wk & CTR 3wks & TT & TTR 2 wk & TTR 3wks \\
\hline FBW (g) & $150.50 \pm 3.49$ & $140.60 \pm 4.40$ & $160.80 \pm 7.30$ & $150.00 \pm 0.00$ & $170.00 \pm 0.00$ \\
\hline TW (\%) & $0.43 \pm 0.02 *$ & $0.46 \pm 0.06^{*}$ & $0.53 \pm 0.04$ & $0.54 \pm 0.04$ & $0.48 \pm 0.04 *$ \\
\hline EW (\%) & $0.12 \pm 0.00^{*}$ & $0.14 \pm 0.00^{*} \dagger$ & $0.15 \pm 0.00^{*}$ & $0.20 \pm 0.00^{*}, \dagger$ & $0.19 \pm 0.01 \dagger$ \\
\hline
\end{tabular}

Final body weight in grams (FBW), Testicular weight (TW) and Epididymis weight (EW) presented as percentage relative organ weight in gram \%. ATR: Ampicillin Treated Recovery, CTR: Cloxacillin Treated Recovery, and TTR: Tetracycline Treated Recovery.

Number of animals $=8$ rats per group. * Significantly different from normal control $(\mathrm{P}<0.05) . \dagger$ Significantly different from corresponding treated group $(\mathrm{P}<0.05)$ 
Histomorphometric findings. The general conditions of the animals in all the groups before and after treatment were good. The treated groups showed significant and meaningful histopathological damage compared with control. This is evidenced by the presence of moderate to severe testicular degeneration, necrosis and sloughing of germinal layers accompanied with vascular congestion and interstitial oedema. The presence of large number of foaming macrophages in all the recovery groups, especially the two weeks recovery group gave evidence in support of repair and regeneration of new cells, while clearing off the old cell debris (Fig. 5a-5d).

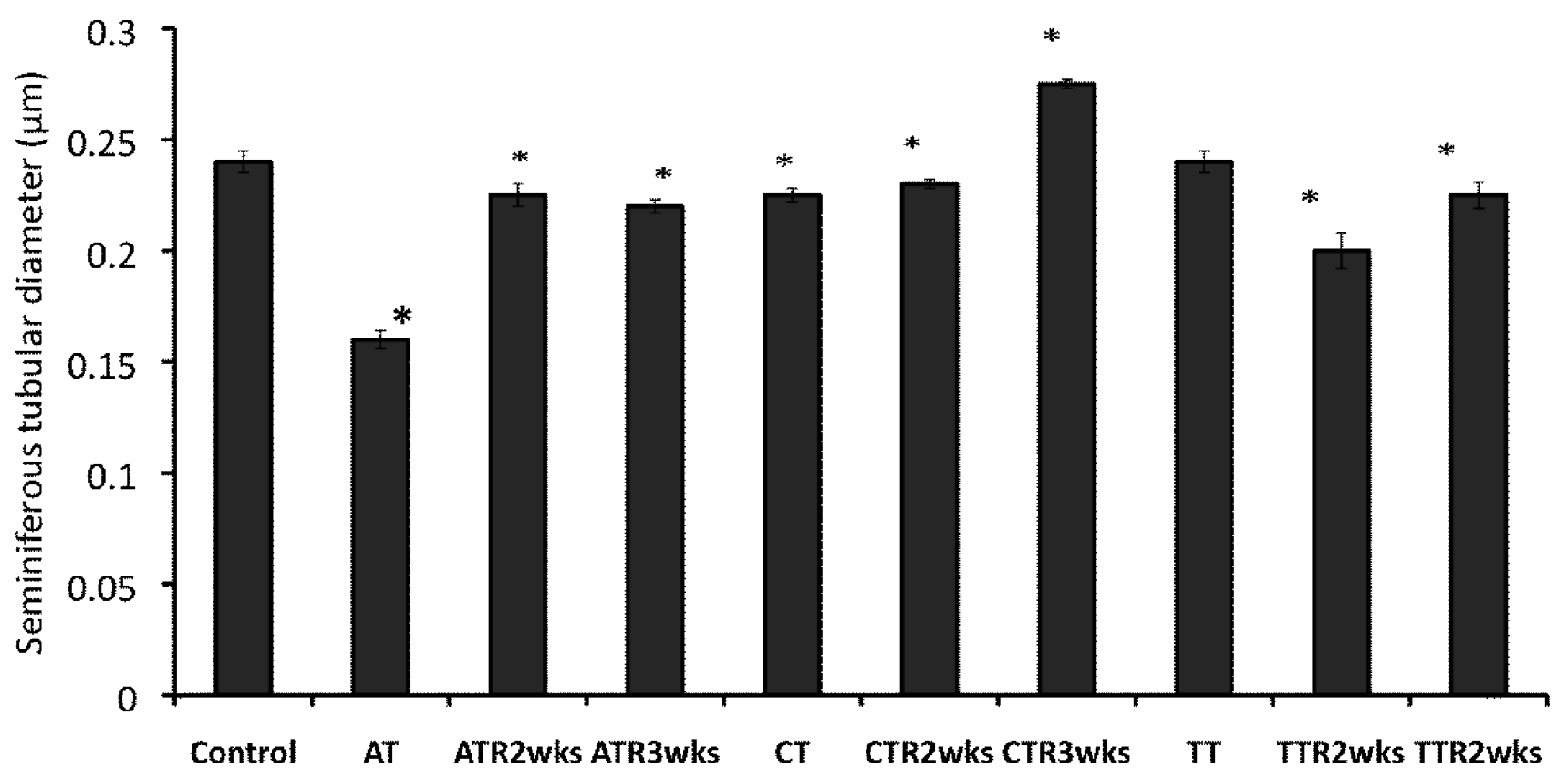

Fig 1. Effects of oral administration of cloxacillin $(6 \mathrm{mg} / 100 \mathrm{~g} / \mathrm{day})$, ampicillin $(4 \mathrm{mg} / 100 \mathrm{~g} / \mathrm{day})$, and tetracycline $(12 \mathrm{mg} / 100 \mathrm{~g} / \mathrm{day}) \mathrm{on}$ rats testicular histomorphometrics as assessed by Seminiferous Tubular Diameter (STD) compared with that of the control. *Significantly different $(\mathrm{p}<0.05)$.

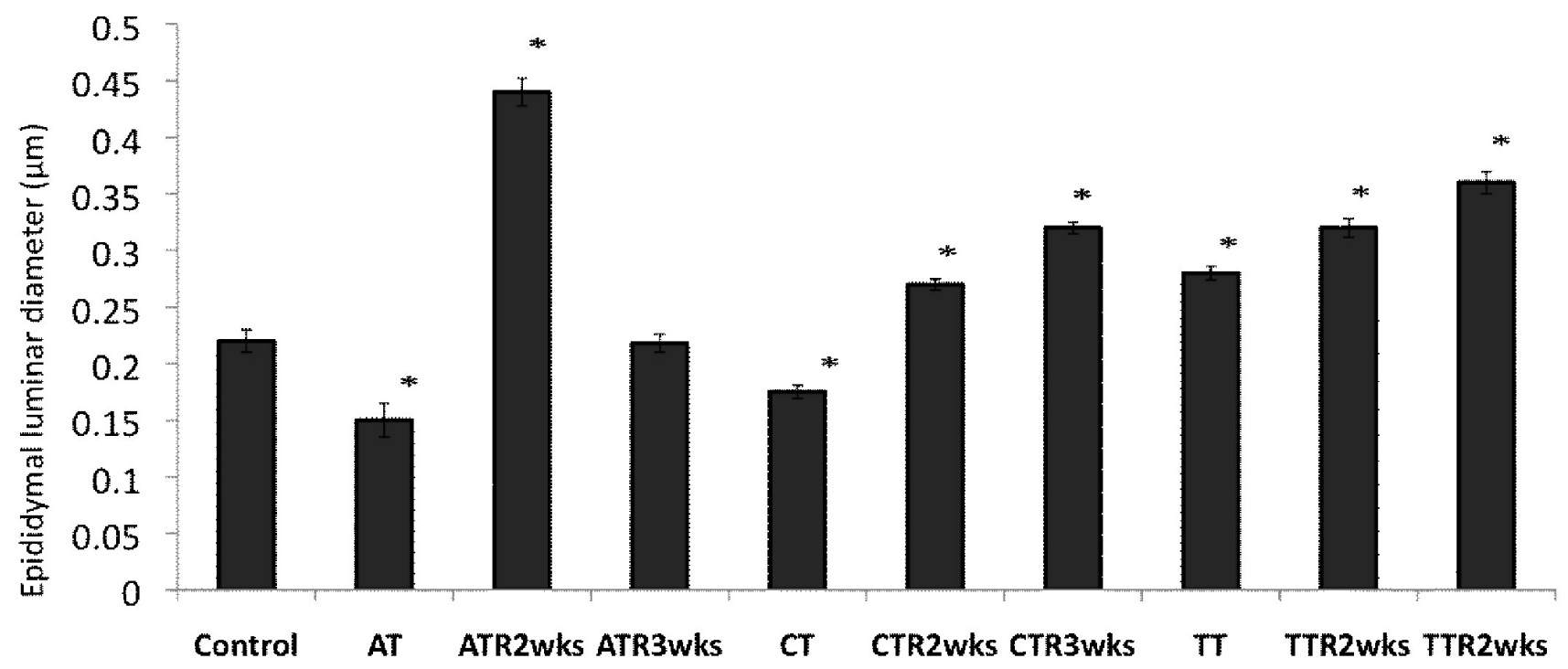

Fig 2. Effects of oral administration of cloxacillin $(6 \mathrm{mg} / 100 \mathrm{~g} /$ day), ampicillin $(4 \mathrm{mg} / 100 \mathrm{~g} /$ day $)$, and tetracycline (12mg/100g/day) on rats testicular histomorphometrics as assessed by Epididymal Lumina Diameter (ELD) compared with that of the control. *Significantly different $(\mathrm{p}<0.05)$. 


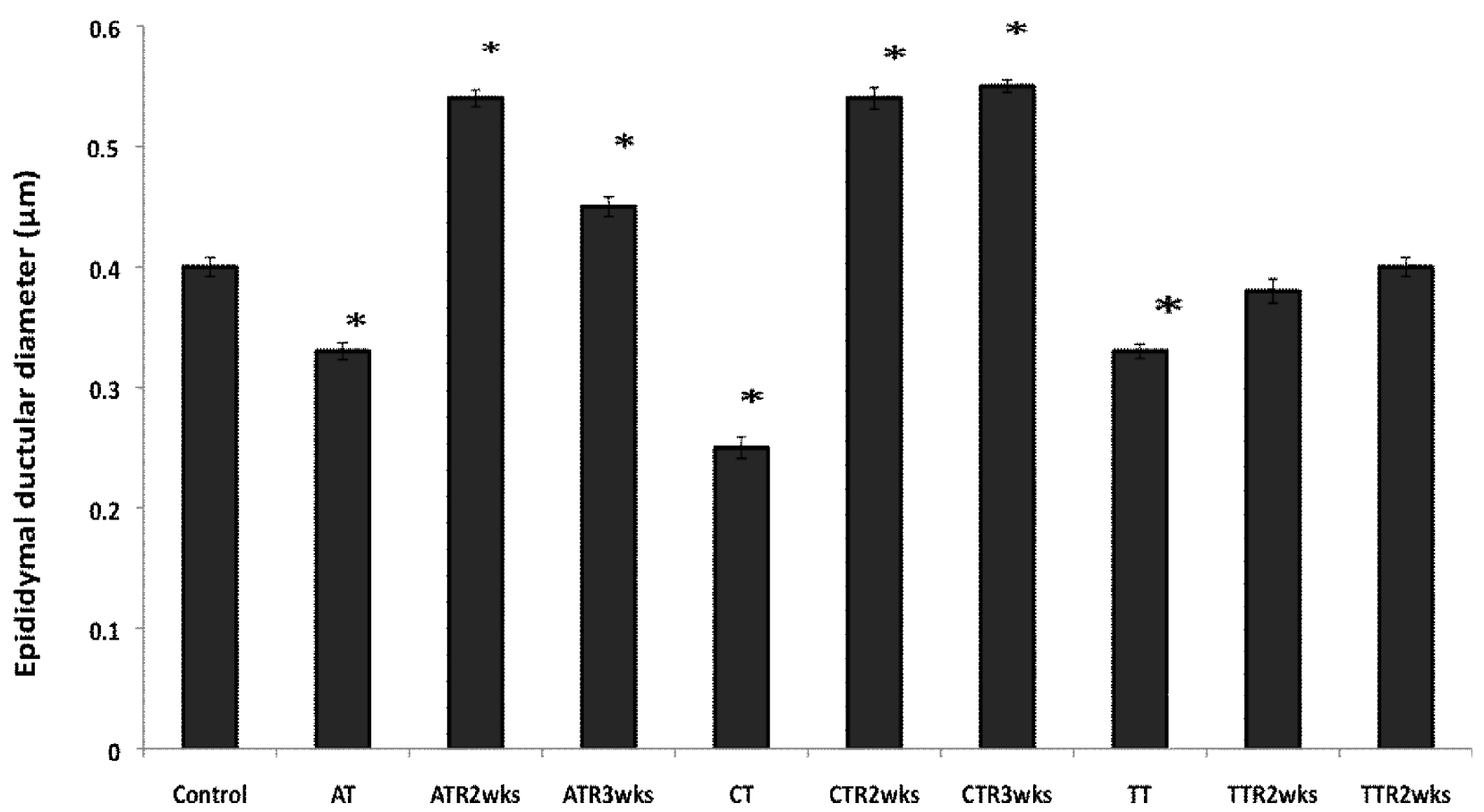

Fig. 3. Effects of oral administration of cloxacillin $(6 \mathrm{mg} / 100 \mathrm{~g} /$ day $)$, ampicillin $(4 \mathrm{mg} / 100 \mathrm{~g} /$ day $)$, and tetracycline $(12 \mathrm{mg} / 100 \mathrm{~g} / \mathrm{day}) \mathrm{on}$ rats testicular histomorphometrics as assessed by Epididymal Ductular Diameter (EDD) compared with that of the control. *Significantly different $(\mathrm{p}<0.05)$.

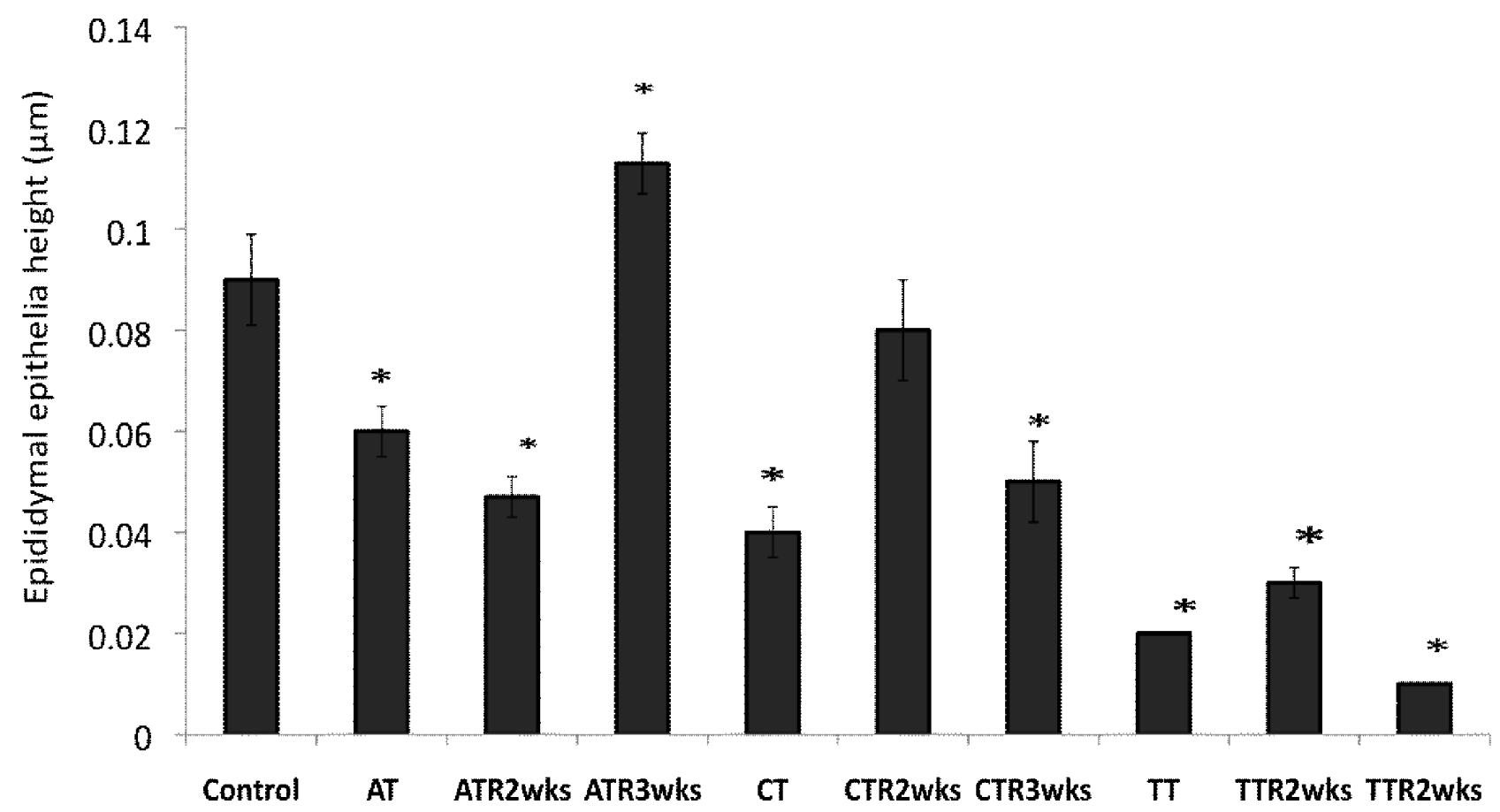

Fig. 4. Effects of oral administration of cloxacillin $(6 \mathrm{mg} / 100 \mathrm{~g} /$ day $)$, ampicillin $(4 \mathrm{mg} / 100 \mathrm{~g} / \mathrm{day})$, and tetracycline $(12 \mathrm{mg} / 100 \mathrm{~g} / \mathrm{day}) \mathrm{on}$ rats testicular histomorphometrics as assessed by Epididymal Epithelial Height (EEH) compared with that of the control. 

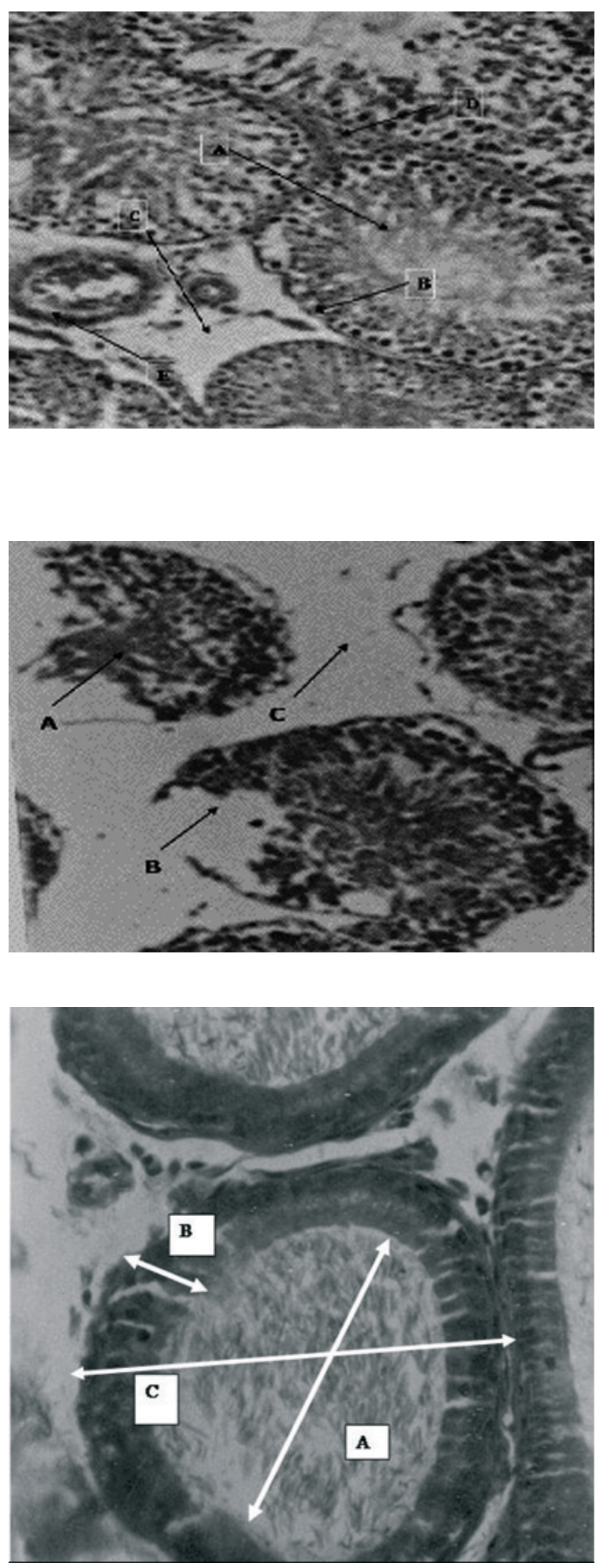
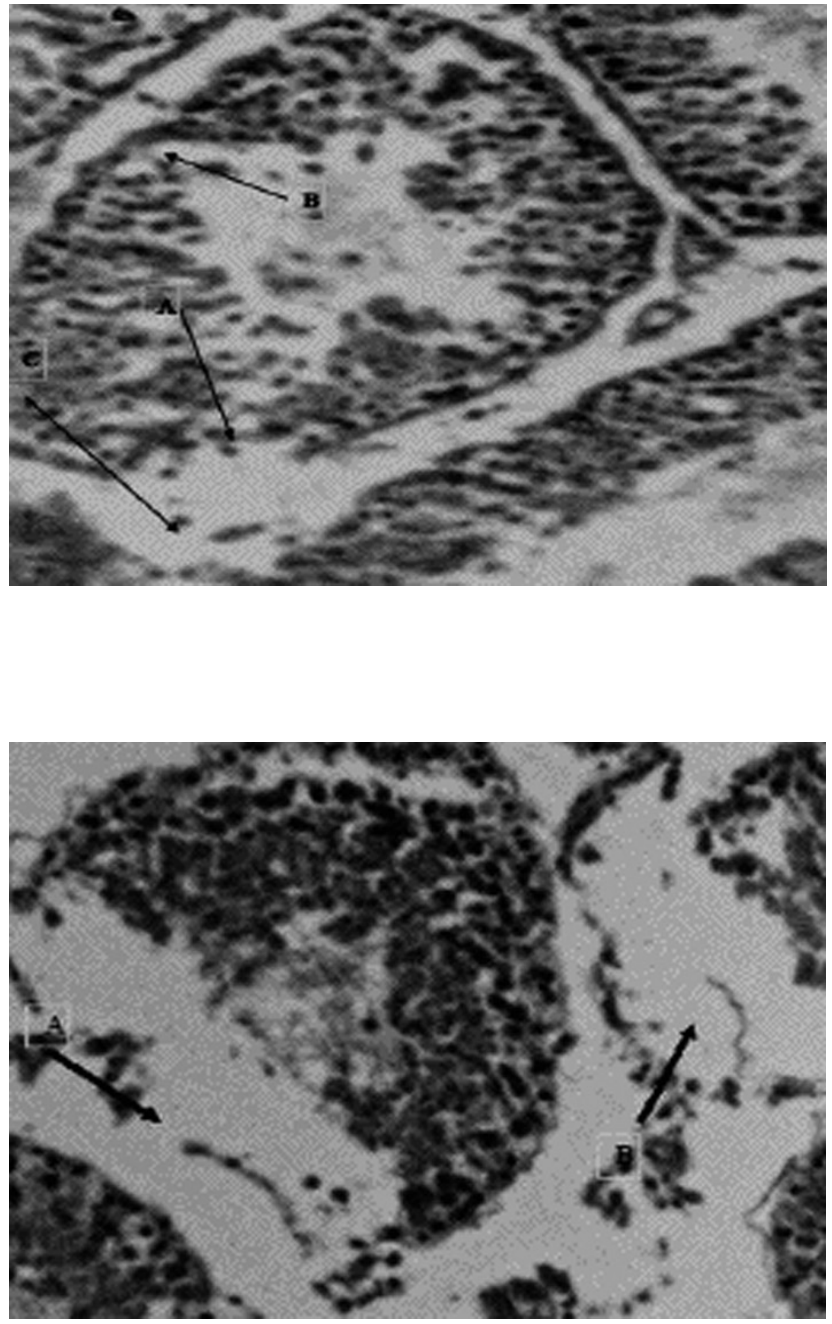

Fig. 5a. Light micrograph of the testicular tissue in Vehicle treated rat (Control). Arrows showing intact lumen of seminiferous tubule (arrow A), intact basement membrane and sertoli cells (arrow B), intact interstitial tissue (arrow C), cells of Leydig, and peritubular capillaries and venules. (H \& E stain.).

Fig. 5b. Light micrograph of the testicular tissue in rat administered therapeutic dose of ampicillin orally for 2 weeks, with arrows showing slight seminiferous tubular degeneration (arrow A) with scattered areas of interstitial edema ( C). There was also necrosis of the sertoli cell responsible for supporting developing spermatocytes(arrow B). (H \& E stain.).

Fig. 5c. Light micrograph of the testicular tissue in rat administered therapeutic dose of cloxacillin orally for 2 weeks treated with arrows showing moderate (arrow A \& B) to severe degeneration of the seminiferous tubules and shrinkage (arrow C). (H \& E stain.).

Fig. 5e. Light micrograph of epididymal tissue from the Control rat with arrow showing the epididymal luminal diameter (A), epididymal epithelia height (B), and epidydimal ductular diameter (C). ). (H \& E stain). 


\section{DISCUSSION}

Histopathology evaluations of test animal tissues is been said to have a prominent role in male reproductive risk assessment. It provides information on the severity of the toxicity and cellular site of the damage as well as the possible potential for recovery (USEPA, 1996). The results of the wet organ weight from rats treated orally with the therapeutic doses of the ampicillin, cloxacillin, and tetracycline for fourteen days showed that there significant $(\mathrm{P}<0.05)$ reduction in testicular and epididymal weight in ampicillin and cloxacillin treated groups where degenerative changes in the testicular histology were also recorded (Table I, Fig. 5b, 5c). The tetracycline treated group also recorded a significant $(\mathrm{p}<0.05)$ reduction in epididymal weight (Table I, Fig 5d). A decrease in EDD and EEH observed in all the tested groups may be due to cell loss leading to sloughing and resultant tubular atrophy. The observed degenerative changes were associated with significant reduction in testicular and epididymal weight. This is in agreement with previous findings of the antifertility effects of many antibiotics (Shlegel et al.). It has been well documented that several qualities of the spermatozoa were influenced by the epididymis: the metabolism, the functions of cell membrane, the fertilizing capacity, the ability to bind to zonae pellucidae of the oocytes and the motility. The motility depends on the electrolytes, androgenes, cAMP-system and the forward motility protein in the epididymis (Awobajo et al., 2006).
In addition, the deleterious effect of long term use of these antibiotics on testicular morphometric as pictured in fig $5 b, 5 c$ and $55 d$ is an evidence of interference with the highly sensitive testicular micro-environment resulting in the disruption of the initiation and maintenance of the spermatogenesis. We have earlier reported a decrease serum testosterone level in animals treated with these antibiotics (Awobayo et al.).

However, these negative effects vis a vis testicular morphological disruption appear to be reversible after the withdrawal of the treatment as regeneration changes both in term of the histomorphometry of the tissue as well as by the increase in the concentration of the macrophages that are known for clearing of cellular debris during tissue repair (Leor et al., 2006). A significant increase $(\mathrm{p}<0.05)$ was recorded in epididymal lumina diameter (ELD) in all the animals after the two and three week's recovery period allowed.

This work suggests that long-term use of these antibiotics even at therapeutic doses (or their abuse) could produce a deleterious effect on testicular histomorphology leading to reduced fertility. Also, the testicular histomorphometry atrophy recorded in animals treated with the antibiotics studied may provide explanation for the reduction in serum testosterone level earlier reported (Awobayo et al.) as leydig cells are responsible for the synthesis of testosterone.

AWOBAJO, F. O.; RAJI Y. \& AKINLOYE, A. K. Cambios histomorfométricos en los testículos y el epidídimo de ratas cepa Wistar Albinas después de catorce días de administración oral de dosis terapéuticas de algunos antiobióticos. Int. J. Morphol., 28(4):12811287, 2010.

RESUMEN: Estudios referentes a testículos y tejido epididimario en ratas tratadas por vía oral durante catorce días, con dosis terapéuticas de cloxacilina (6mg/100g/día), ampicilina (4mg/100/día) y tetraciclina (12mg/100g/día) por separado muestran una reducción significativa en el peso testicular y epidídimario. Los estudios microscópicos de los órganos reproductores masculinos revelan además una alteración significativa en el epidídimo como se observa en la reducción del diámetro ( $<<0,05)$ de los conductos del epidídimo (EDD), y la altura del epitelio epididimal (EEH) en el grupo de los animales tratados. Sin embargo, se registró un aumento significativo $(\mathrm{p}<0,05)$ en el diámetro luminal del epidídimo (ELD) en todos los animales después de dos y tres semanas del período de recuperación. Esto genera otro punto de vista en relación a la toxicidad de estos antibióticos en los órganos reproductivos masculinos, además de la reducción de la concentración sérica de testosterona, disminución de la motilidad del esperma, disminución del recuento de espermatozoides y disminución en el contenido de ARN y ADN en las células de espermatogénesis como se reportó anteriormente.

\section{PALABRAS CLAVE: Antibióticos; Testículos; Epidídimo; Histomorfometría.}

\section{REFERENCES}

Akinloye, A. K.; Abatan, M. O.; Alaka, O. O. \& Oke, B. O. Histomorphometric and Histopathological studies on the effect of Calotropis procera (giant milkweed) on the male reproductive organs of wistar rats. Afr. J. Biomed. Res., 5:57-61, 2002.
Aumüller, G.; Braun, B. E.; Seitz, J.; Müller, T.; Heyns, W. \& Krieg, M. Effects of sexual rest or sexual activity on the structure and function of the ventral prostate of the rat. Anat. Rec., 212:345-52, 1985. 
Awobajo, F. O.; Raji, Y.; Olatunji-Bello. I. I.; Kunle-Alabi. F. T.; Adesanya, A. O. \& Awobajo, T. O. Fourteen days oral administration of therapeutic dosage of some Antibiotics reduced serum Testosterone in male rats. Niger J. Health Biomed. Sci., 5:17-20, 2006.

Bustos-Obregon, E. \& Gonzalez-Hormazabal, P. Effect of a single dose of malathion on spermatogenesis in mice. Asian J. Androl., 2:105-7, 2003.

Fawcett, D. W. Bloom and Fawcett: A Textbook of Histology. Philadephia, W. B. Saunders, 1986.

Glander, H. J. Effect of the epididymis on male fertility. $Z$. Urol. Nephrol., 77:551-7, 1984.

Hess, R. A. \& Moore, B. J. Histological methods for evaluation of the testis. In: Chapin, R. E. \& Heindel, J. J. Methods in Toxicology: Male Reproductive Toxicology. San Diego, Academic Press, 1993. pp.5285 .

Leor, J.; Rozen, L.; Zuloff-Shani, A.; Feinberg, M. S.; Amsalem, Y.; Barbash, I. M.; et al. Ex Vivo Activated Human Macrophages Improve Healing, Remodeling, and Function of the Infarcted Heart. Circulation, 114:194100, 2006.

Pierce, G. F.; Mustoe, T. A.; Lingelbach, J.; Masakowski, V. R.; Griffin, G. L.; Senior, R. M.; et al. Platelet-derived growth factor and transforming growth factor-beta enhance tissue repair activities by unique mechanisms. J. Cell Biol., 109:429-40, 1989.

Raji, Y.; Oloyo, A. K. \& Morakinyo, A. O. Studies on the reproductive activities of methanol extract of Ricinus Communis Seed (Linn) on male albino rats. Asian J. Androl., 8:115-21, 2006.

Russell, L. D.; Ettlin, R.; Sinha Hikim, A. P. \& Clegg, E. D. Histological and Histopathological Evaluation of the Testis. Clearwater, FL., Cache River Press, 1990.

Schlegel, P. N.; Chang, T. S. \& Marshall, F. F. Antibiotics: potential hazards to male fertility. Fertil. Steril., 55:23542, 1991.

USEPA, Risk Assessment Forum U.S. Environmental Protection Agency, Washington, (1996). Guidelines for Reproductive Toxicity Risk Assessment DCEPA/630/R96/009. Federal Register USA, 61:56274-322, 1996.

\section{Correspondence to:}

Funmileyi Olubajo Awobajo

Department of Physiology

University of Lagos

NIGERIA

Phone: +23408053416937

Email: funmi_bajo@yahoo.com

Received: 05-06-2010

Accepted: 31-08-2010 
